\title{
Does the Access to Sun Exposure Ensure Adequate Levels of 25-Hydroxyvitamin D?
}

\section{A exposição ao sol assegura níveis adequados de 25-hidroxivitamina $D$ ?}

Ênio Luis Damaso ${ }^{1}$ Francisco José Albuquerque de Paula ${ }^{2}$ Silvio Antônio Franceschini ${ }^{1}$ Carolina Sales Vieira ${ }^{1}$ Rui Alberto Ferriani ${ }^{1}$ Marcos Felipe Silva de Sá ${ }^{1} \quad$ Lucia Alves da Silva Lara ${ }^{1}$

${ }^{1}$ Department of Obstetrics and Gynecology, Faculdade de Medicina de Ribeirão Preto, Universidade de São Paulo (FMRP-USP), Ribeirão Preto, SP, Brazil

${ }^{2}$ Department of Internal Medicine, Faculdade de Medicina de Ribeirão Preto, Universidade de São Paulo, Ribeirão Preto, SP, Brazil
Address for correspondence Ênio Luis Damaso, Rua Romeu Engrácia de Faria, 325, Apartment 34, Nova Aliança, Ribeirão Preto, SP, Brazil (e-mail: eniodamaso@yahoo.com.br).

Rev Bras Ginecol Obstet 2017;39:102-109.

\section{Abstract \\ Keywords \\ - Female Gender \\ - 25-hydroxyvitamin D \\ - vitamin D deficiency \\ - sun exposure}

\section{Resumo}

\section{Palavras-chave}

- sexo feminino

- 25-hidroxhvitamina D

- deficiência de vitamina D

- exposição ao sol
Objectives To assess the prevalence of hypovitaminosis D, altered arterial blood pressure, and serum levels of glucose and lipids in community-dwelling women in the city of Ribeirão Preto, in the southeast of Brazil.

Methods This was a cross-sectional study of women aged $40-70$ years old. Calcium intake and level of sun exposure were assessed by means of a questionnaire. A blood sample was used to determine glucose, lipid profile and 25-hydroxyvitamin D (25[OH]D) concentration. Results Ninety-one women were enrolled (age $=54.2 \pm 7.1$ years). The mean serum $25(\mathrm{OH}) \mathrm{D}$ concentration was $25.7 \pm 8.9 \mathrm{ng} / \mathrm{mL}$. A total of $24(26.4 \%)$ women had 25 $(\mathrm{OH})$ D levels $<20 \mathrm{ng} / \mathrm{mL}$. Seventy women (76.9\%) had 25(OH)D levels $<30 \mathrm{ng} / \mathrm{mL}$. Seventy-five women (90.4\%) had inadequate calcium intake, and 61 women (67\%) had appropriate sun exposure, 49 of whom (80.3\%) had serum 25(OH)D levels $<30 \mathrm{ng} / \mathrm{mL}$. Conclusion This study indicates that even in community-dwelling women, living in a city with high sun exposure, serum levels of $25(\mathrm{OH}) \mathrm{D}>30 \mathrm{ng} / \mathrm{ml}$ are hardly reached. Thus, it is probable that other intrinsic factors besides sun exposure may regulate the levels of vitamin D.

Objetivos Estimar a prevalência de hipovitaminose D, hipertensão arterial, e níveis séricos de glicose e perfil lipídico em uma comunidade de mulheres de Ribeirão Preto, no Sudeste brasileiro.

Métodos Estudo transversal com mulheres de 40 a 70 anos de idade, submetidas a um questionário para determinar ingestão diária de cálcio e nível de exposição solar, e coleta de sangue para determinar glicose, perfil lipídico e concentração de 25hidroxivitamina D (25[OH]D).

Resultados Noventa e uma mulheres foram incluídas (idade $=54,2 \pm 7,1$ anos). 0 nível sérico médio de $25(\mathrm{OH}) \mathrm{D}$ foi $25,7 \pm 8,9 \mathrm{ng} / \mathrm{mL}$. Um total de $24(26,4 \%)$ mulheres received

March 23, 2016

accepted

January 9, 2017

published online

March 15, 2017
Copyright $\odot 2017$ by Thieme-Revinter

Publicações Ltda, Rio de Janeiro, Brazil
License terms

10.1055/s-0037-1600520. ISSN 0100-7203.

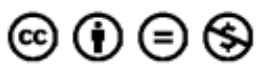


teve níveis de $25(\mathrm{OH}) \mathrm{D}<20 \mathrm{ng} / \mathrm{mL}$. Setenta mulheres (76.9\%) tiveram níveis de 25 $(\mathrm{OH}) \mathrm{D}<30 \mathrm{ng} / \mathrm{mL}$. Setenta e uma mulheres $(90.4 \%)$ tiveram uma ingesta inadequada de cálcio e 61 mulheres (67\%) tiveram exposição solar adequada; 49 das quais (80.3\%) tiveram níveis séricos de $25(\mathrm{OH}) \mathrm{D}<30 \mathrm{ng} / \mathrm{mL}$.

Conclusão Este estudo indica que mesmo morando em uma cidade com exposição solar adequada, níveis séricos de 25(OH)D $>30 \mathrm{ng} / \mathrm{mL}$ dificilmente são atingidos por mulheres climatéricas. Logo, é provável que outros fatores intrínsecos podem regular o nível de vitamina $\mathrm{D}$.

\section{Introduction}

Vitamin D, classically, was considered a hormone specialized in the control of bone and mineral metabolism. However, the role of vitamin $\mathrm{D}$ on human physiology has been completely re-dimensioned due to new evidences indicating that vitamin $\mathrm{D}$ is a pleiotropic hormone able to participate in the endocrine control of several systems, such as: cardiovascular, energy metabolism and immune. ${ }^{1}$ Vitamin $\mathrm{D}_{3}$ (cholecalciferol) and vitamin $D_{2}$ (ergocalciferol) are the two main forms of vitamin, and act as prohormones. The ultraviolet radiation in sunlight promotes vitamin $\mathrm{D}_{3}$ synthesis in the skin, and this accounts for $\sim 60-80 \%$ of the required amount. ${ }^{1}$ The non-enzymatic conversion of pro- to pre-, and subsequently to vitamin $\mathrm{D}$ formation in response to solar UVB radiation, leads thereafter to the production of the active hormone, through hydroxylation in the liver (forming 25-hydroxyvitamin D [25- OHD $]^{1}$ ( and then $1 \alpha$ hydroxylation in the kidney (synthesizing 1,25-dihydroxyvitamin D $\left.\left[1,25(\mathrm{OH})_{2} \mathrm{D}\right]\right)$. The active form of vitamin $\mathrm{D}, 1,25(\mathrm{OH})_{2} \mathrm{D}$, binds to nuclear receptors of cells in the intestine and kidney, and stimulates calcium and phosphorus absorption. Vitamin $\mathrm{D}$ also binds to osteoclasts and stimulates bone reabsorption. ${ }^{2}$ However, the synthesis of this secosteroid in the skin is tightly controlled to avoid vitamin D intoxication, even during continuous and excessive sun exposure. For instance, melanin production in the skin is stimulated by the sunlight and compete for UVB rays. In addition, inert compounds are synthesized by a thermos-regulated process during the steps of pre- and post-vitamin D formation synthesis within the skin. ${ }^{1}$

There is controversy regarding the healthy range of serum vitamin D. The Institute of Medicine (IOM) proposed that circulatory levels of $25(\mathrm{OH}) \mathrm{D}$ above $20 \mathrm{ng} / \mathrm{mL}$ are adequate for the most part of the population. Moreover, the IOM indicated that severe vitamin $\mathrm{D}$ deficiency occurs only when the 25(OH)D levels are below $12 \mathrm{ng} / \mathrm{mL}^{3}$ On the other hand, the Endocrine Society dictates that vitamin D sufficiency is achieved at levels above $30 \mathrm{ng} / \mathrm{mL}$, while the range from 20 to $30 \mathrm{ng} / \mathrm{mL}$ indicates vitamin D insufficiency and levels below $20 \mathrm{ng} / \mathrm{mL}$ indicate deficiency. ${ }^{2,4}$ Thus, the prevalence of hypovitaminosis $\mathrm{D}$ depends on which recommendations are accepted. ${ }^{5}$

Vitamin D deficiency induces abnormal calcium, phosphorus, and bone metabolism. A reduced level of vitamin D decreases intestinal calcium absorption, thereby increasing the level of parathyroid hormone $(\mathrm{PTH})$, which in turn stimulates the renal synthesis of $25(\mathrm{OH}) \mathrm{D}-1 \alpha$-hydroxylase, the renal enzyme that converts $25(\mathrm{OH}) \mathrm{D}$ into $1,25(\mathrm{OH})_{2} \mathrm{D}$. The elevation of PTH also increases osteoclast activity, causing bone loss and, ultimately, leading to osteopenia and osteoporosis. Vitamin D deficiency has also been associated with muscle weakness, and increased fall risk in adults and elderly individuals, ${ }^{2,6}$ as well as with metabolic diseases, ${ }^{7,8}$ and insulin resistance. ${ }^{9}$

In most individuals, the serum level of vitamin $\mathrm{D}$ is higher in the summer than in the winter. ${ }^{10}$ Previous research estimated that a large number of adult men and women suffer from hypovitaminosis D, and that the elderly are the most affected. ${ }^{2,11,12}$ Even though Brazil is situated in the tropics and subtropics, previous study indicated a high prevalence of hypovitaminosis D in some subpopulations from certain regions. ${ }^{13}$

The metabolic consequences of the vitamin D status are shown in recent studies; hypertension and endothelial dysfunction, ${ }^{14}$ as well as dyslipidemia ${ }^{15}$ are associated with low levels of $25(\mathrm{OH}) \mathrm{D}$. Supplemental vitamin D and calcium are frequently recommended for preservation of bone mass, ${ }^{16}$ although regular sun exposure is the simplest method to attain an adequate level of vitamin $D$. In particular, exposure to 5 to 15 minutes of sunlight between $10 \mathrm{Am}$ and $3 \mathrm{PM}$ in the spring, summer, and fall is sufficient for maintenance of adequate levels of vitamin D. ${ }^{17}$ Although Brazil has a continental size, most of his territory has abundant incidence of sun light, supposedly, precluding a high incidence of D hypovitaminosis. The main objective of the present study was to assess the prevalence of hypovitaminosis D in community-dwelling women from Ribeirão Preto, a sunny city in the southeast of Brazil

\section{Methods}

Women aged 40 to 70 years old who came to the Climacteric Outpatient Clinic of the Centro de Saúde Escola Sumarezinho from January to December of 2013 for routine gynecological visits were eligible for participation in this cross-sectional study. The nursing staff informed all women about the study, and invited them to participate. Institutionalized women, and women who had limited movement without the help of devices (ortheses, prostheses, wheelchairs, etc.) or of other 
people were excluded because such individuals are known to have low serum levels of vitamin D. ${ }^{18} \mathrm{~A}$ total of 150 women were invited to participate in this study, 110 of whom agreed to it. Nineteen of these women were excluded because they did not undergo blood collection, and 91 women were ultimately enrolled.

In a private office, a doctor evaluated each participant using a semi-structured interview that asked about the use of medications (hormones, supplemental vitamin D and/or calcium), consumption of calcium-rich foods, duration of sun exposure, and duration of weekly physical activity.

Body mass index was estimated in all subjects and they were classified in accordance with the World Health Organization classification: underweight $\left(\mathrm{BMI}<18.5 \mathrm{~kg} / \mathrm{m}^{2}\right)$, normal weight $\left(B M I=18.5-24.9 \mathrm{~kg} / \mathrm{m}^{2}\right)$, grade I overweight $\left(\mathrm{BMI}=25-29.9 \mathrm{~kg} / \mathrm{m}^{2}\right)$, grade II overweight $(\mathrm{BMI}=$ $30-39.9 \mathrm{~kg} / \mathrm{m}^{2}$ ), or grade III overweight (BMI $\geq 40 \mathrm{~kg} / \mathrm{m}^{2}$ ).

A blood sample was collected between March and June of 2013 (fall and winter in Brazil) for measurement of serum 25(OH)D levels, ionized calcium, fast glucose, and lipid profile. Also, creatinine was measured as it is negatively correlated with vitamin D levels. ${ }^{19}$ Renal function was assessed by measurement of serum creatinine by automated spectrophotometry (Wiener Laboratory, Rosario, Santa Fe, Argentina). Serum 25(OH)D was determined by a chemiluminescence immunoassay using the LIAISON 25 OH Vitamin D TOTAL assay (DiaSorin, Saluggia, Italy). Glucose was determined by automated spectrophotometry using the AA liquid enzymatic glycaemia kit (Wiener Laboratory, Rosario, Santa Fe, Argentina). Ionized calcium was determined by automated spectrophotometry using the Arsenazo III AA kit (Wiener Laboratory, Rosario, Santa Fe, Argentina). Serum total cholesterol, HDL, and triglycerides were determined by automated spectrophotometry (Wiener Laboratory, Rosário, Santa Fe, Argentina).

Consumption of calcium was estimated according to the milk and dairy products data in the food composition table suggested by the US Department of Agricultural Research Service. ${ }^{20}$

Sun exposure was estimated based on self-reported outdoor time and based on the professional and life habits of each subject. Exposure was considered adequate if at least $20 \%$ of the body surface (face, neck, arms, and legs) was exposed for at least 10 minutes, 3 or more times per week between $10 \mathrm{Am}$ and $3 \mathrm{PM}^{17}$ and inadequate when the exposure was below this mark. The duration of physical activity (walking) was classified based on the time recommended for the prevention of osteoporosis by the American College of Sports' Guidelines for Exercise Testing and Prescription ${ }^{21}: 20$ to 40 minutes of exercise, 2 to 4 times per week.

Based on indications of the Endocrine Society, serum 25 $(\mathrm{OH})$ D concentration was classified as deficient $(<20 \mathrm{ng} / \mathrm{mL})$, insufficient (21-29 ng/mL), or sufficient (30-100 ng/mL). ${ }^{2,4}$

\section{Statistical Analysis}

All statistical procedures were performed using the PROC MEANS and PROC FREQ features of the SAS 9.0 (Cary, NC,
USA) software. For the description of quantitative variables, mean and standard deviation were calculated. For qualitative variables, the absolute and relative frequencies were calculated. Fisher exact test was used to determine the association between two qualitative variables. Women with vitamin $\mathrm{D}$ deficiency $(<20 \mathrm{ng} / \mathrm{ml})$ and adequate vitamin D levels were compared in terms of qualitative variables (systemic hypertension, diabetes mellitus, hypothyroidism, alcoholism, smoking, physical activity and sun exposure) and quantitative variables (age, BMI, serum calcium, blood glucose, HDL, total cholesterol, triglycerides and creatinine). Exploratory data analysis was performed through central position measurements and dispersion. Data distribution was checked by normal graphics. A non-parametric Mann Whitney test was used to compare quantitative variables between groups. The chi-square test was used to compare the distributions of qualitative variables in the groups. The variable sun exposure was dichotomized with cutoff of three times a week as adequate exhibition. A model of logistic regression was performed to verify the influence of the variables age, creatinine and sun exposure in relation to vitamin D concentration. Significance was set at $p<0.05$.

\section{Results}

Ninety-one women participated in the study. - Table 1 shows the demographic, laboratory and clinical characteristics of the enrolled women.

Mean serum 25(OH)D was $25.7 \pm 8.9 \mathrm{ng} / \mathrm{mL}$. A total of 24 (26.4\%) women had 25(OH)D levels $<20 \mathrm{ng} / \mathrm{mL}$. Seventy women (76.9\%) had 25(OH)D levels $<30 \mathrm{ng} / \mathrm{mL}$ (18 of 20 black women [90\%] and 54 of 71 white women [76\%]) and 21 (23.1\%) women had sufficient 25(OH)D levels ( $\geq 30 \mathrm{ng} / \mathrm{mL}$ ). Serum 25(OH)D concentration was dichotomized as $<20 \mathrm{ng} / \mathrm{ml}$ and $\geq 20 \mathrm{ng} / \mathrm{ml}$. - Table 2 shows the distribution of the studied qualitative variables and the comparison between groups regarding the incidence of these variables according to the vitamin D levels. There was no difference between women with vitamin D deficiency regarding the incidence of hypertension, diabetes mellitus, hypothyroidism, and habits of smoking and drinking. Also, there was no difference between women with adequate amount of physical activity and adequate sun exposure (-Table 2).

- Table 3 shows the distribution of the studied quantitative variables and the comparison between groups of the incidence of such variables. There was no significant difference between women with vitamin D deficiency regarding age, BMI, and dosage of calcium, fast glucose, lipid profile, and creatinine.

Based on recall, average calcium consumption was $560.4 \pm 435.8 \mathrm{mg} /$ day, and 75 women (90.4\%) had inadequate calcium intake ( $<1200 \mathrm{mg} /$ day). Sixty-one women (67\%) reported adequate sun exposure and 49 of these women (80.3\%) had serum 25(OH)D levels $<30 \mathrm{ng} / \mathrm{mL}$.

There was no significant difference in the serum $25(\mathrm{OH}) \mathrm{D}$ concentration for women with adequate and inadequate sun exposure ( $p=0.88,-$ Fig. $\mathbf{1 A})$. In addition to this, there was 
Table 1 Anthropometric, laboratory, and clinical characteristics of the enrolled women $(n=91)$

\begin{tabular}{|c|c|}
\hline Variable & Mean \pm SD or $\mathrm{n}(\%)$ \\
\hline Age (years) & $54.2 \pm 7.1$ \\
\hline BMI $\left(\mathrm{kg} / \mathrm{m}^{2}\right)$ & $27.1 \pm 4.8$ \\
\hline 25(OH)D (ng/mL) & $25.7 \pm 8.9$ \\
\hline Calcium ion (mmol/L) & $1.09 \pm 0.05$ \\
\hline Glucose (mg/dL) & $90.4 \pm 18.5$ \\
\hline Total cholesterol (mg/dL) & $187.1 \pm 38.5$ \\
\hline HDL-C (mg/dL) & $46.6 \pm 11.8$ \\
\hline Triglycerides (mg/dL) & $115.2 \pm 59.9$ \\
\hline Creatinine (mg/dL) & $0.80 \pm 0.11$ \\
\hline \multicolumn{2}{|l|}{ Diseases } \\
\hline Arterial hypertension & 30 (32.9) \\
\hline Hypothyroidism & $11(12.0)$ \\
\hline Diabetes mellitus & $7(7.6)$ \\
\hline Dyslipidemia & $15(16.4)$ \\
\hline Other & $25(27.4)$ \\
\hline None & $28(30.7)$ \\
\hline \multicolumn{2}{|l|}{ Race } \\
\hline White & $71(78.0)$ \\
\hline Mulatto/Black & 20 (21.9) \\
\hline \multicolumn{2}{|l|}{ Habits } \\
\hline Smoking (Yes) & $11(12.0)$ \\
\hline Alcohol ingestion (Yes) & $20(22)$ \\
\hline \multicolumn{2}{|l|}{ Physical activity } \\
\hline$\leq 150$ minute/week & $76(83.5)$ \\
\hline
\end{tabular}

Abbreviations: $\mathrm{BMI}$, body mass index; $\mathrm{HDL}-\mathrm{C}$, high-density lipoprotein cholesterol; $n$, number of subjects; SD, standard deviation

no significant difference in serum concentration of ionized calcium for women with adequate and inadequate calcium consumption ( $p=0.73$, - Fig. 1B).

Finally, we used multiple linear regression analysis to determine the effect of sun exposure, age, and serum creatinine on serum 25(OH)D concentration (-Table 4). The results show that a normal level of serum creatinine was significantly and independently associated with a higher level of serum 25(OH)D. The other variables had no significant effect on the levels of serum 25(OH)D.

\section{Discussion}

The present study of women living in a sunny subtropical region indicated a high prevalence $(76.9 \%)$ of vitamin $\mathrm{D}$ insufficiency $(<30 \mathrm{ng} / \mathrm{mL})$, even in women whose selfreported sun exposure was considered to be adequate. Moreover, $26.4 \%$ of the women had a deficiency of vitamin D (serum $25(\mathrm{OH}) \mathrm{D}<20 \mathrm{ng} / \mathrm{mL}$ ). These findings confirm previous studies conducted in other Brazilian cities at dif- ferent latitudes. ${ }^{18,22}$ The frequency of arterial hypertension and dyslipidemia in our study were similar in women with sufficient and deficient 25(OH)D levels. In fact, vitamin D supplementation in hypertensive patients with low 25(OH)D had no significant effect on blood pressure (BP) and several cardiovascular risk factors. ${ }^{23}$ Also, long-term vitamin D supplementation, which increased mean $25(\mathrm{OH}) \mathrm{D}$ concentration to $30 \mathrm{ng} / \mathrm{mL}$ or higher, had no effect on BP. ${ }^{24}$ Furthermore, oral vitamin $\mathrm{D}$ supplementation to correct vitamin $\mathrm{D}$ deficiency does not improve the lipid profile. ${ }^{25}$ It is worth to emphasize that the relationship between vitamin $\mathrm{D}$ and cardiovascular disease, as well as other clinical conditions, comes from observational studies, while further controlled studies do not show such a relationship

In the southeast region of Brazil, $43.7 \%$ of postmenopausal women have $25(\mathrm{OH}) \mathrm{D}$ levels $<20 \mathrm{ng} / \mathrm{mL}$, and $25(\mathrm{OH}) \mathrm{D}$ deficiency increases significantly with age. ${ }^{22}$ The São Paulo Aging \& Health Study evaluated individuals older than 65 years old in the city of São Paulo and reported 25(OH)D deficiency in more than half of this population, and this deficiency was particularly notable in women, subjects with type 2 diabetes, and during the winter and spring, ${ }^{26}$ seasons when ultraviolet radiation and $25(\mathrm{OH}) \mathrm{D}$ concentrations reach a nadir in the city of São Paulo. ${ }^{27}$ World data demonstrate that 5 to $25 \%$ of the independent elderly population and 60 to $80 \%$ of institutionalized patients have vitamin D deficiencies. ${ }^{28}$ Likewise, 20 to $100 \%$ of elderly subjects in North America, Canada, and Europe,, 211 as well as postmenopausal women living in southeastern and central Europe ${ }^{29}$ are believed to have vitamin $\mathrm{D}$ deficiencies. We did not expect a high prevalence of $25(\mathrm{OH}) \mathrm{D}$ insufficiency/ deficiency in the present study because these women live in a region that is sunny throughout the year, and wear warm clothing for only short periods of time. Furthermore, this region has high agricultural activity, and the population is frequently exposed to sunlight. Nevertheless, only a minority of these women had sufficient levels of 25(OH)D (>30 ng/mL). ${ }^{4}$ This is clinically significant because previous observational studies demonstrated that hypovitaminosis D is associated with some clinical conditions, such as cardiovascular diseases, secondary hyperparathyroidism, osteoporosis, and fractures. ${ }^{18,30,31}$

A previous population-based study of osteoporosis in Brazil (BRAZOS) indicated that vitamin D levels did not affect the risk for fractures, ${ }^{32}$ possibly because fractures are associated with polymorphisms of the vitamin D receptors. However, several previous studies failed to establish this correlation in Brazilian and British populations. ${ }^{33,34}$ Moreover, associations between 25(OH)D levels with other clinical conditions were reported in some but not all observational studies, ${ }^{35}$ and the results from randomized and controlled clinical trials are not yet available. These observational trials were also limited due to small sample sizes and short duration, which affected the quality of the investigations. ${ }^{36,37}$ On this basis, the current recommendation is to measure serum 25(OH)D levels only in situations in which there is a risk for hypovitaminosis D due to certain morbidities. ${ }^{4}$ This implies that the information given by patients 
Table 2 Distribution of qualitative variables according to vitamin D cutoff classification as deficient $[<20 \mathrm{ng} / \mathrm{mL}]$ and adequate $[\geq 20 \mathrm{ng} / \mathrm{mL}]$ ) vitamin D levels.

\begin{tabular}{|c|c|c|c|}
\hline & \multicolumn{2}{|l|}{ Vitamin D levels } & \multirow[t]{2}{*}{$p$} \\
\hline & $<20 \mathrm{ng} / \mathrm{mL}(n=24)$ & $\geq 20 \mathrm{ng} / \mathrm{mL}(n=67)$ & \\
\hline \multicolumn{4}{|l|}{ Arterial hypertension } \\
\hline Yes & 7 (29.1\%) & $23(34.3 \%)$ & 0.64 \\
\hline No & $17(70.8 \%)$ & $44(65.6 \%)$ & \\
\hline \multicolumn{4}{|l|}{ Diabetes Mellitus } \\
\hline Yes & $2(8.3 \%)$ & $5(7.4 \%)$ & 0.91 \\
\hline No & $22(91.6 \%)$ & $62(92.5 \%)$ & \\
\hline \multicolumn{4}{|l|}{ Hypothyroidism } \\
\hline Yes & $2(8.3 \%)$ & 9 (13.4\%) & 0.51 \\
\hline No & $22(91.6 \%)$ & $58(86.5 \%)$ & \\
\hline \multicolumn{4}{|l|}{ Alcohol ingestion } \\
\hline Yes & $6(25.0 \%)$ & $14(20.9 \%)$ & 0.68 \\
\hline No & $18(75.0 \%)$ & $53(79.1 \%)$ & \\
\hline \multicolumn{4}{|l|}{ Smoking } \\
\hline Yes & $5(20.8 \%)$ & $6(8.9 \%)$ & 0.13 \\
\hline No & $19(7.1 \%)$ & $61(91.0 \%)$ & \\
\hline \multicolumn{4}{|l|}{ Physical activity } \\
\hline None & $2(8.3 \%)$ & $3(4.6 \%)$ & 0.14 \\
\hline$\leq 150$ minute/week & $21(87.5 \%)$ & $48(73.8 \%)$ & \\
\hline$>150$ minute/week & $1(4.1 \%)$ & $14(21.5 \%)$ & \\
\hline \multicolumn{4}{|l|}{ Sun exposure } \\
\hline Adequate & $17(7.8 \%)$ & $51(7.2 \%)$ & 0.53 \\
\hline Inadequate & 7 (29.1\%) & $15(2.7 \%)$ & \\
\hline
\end{tabular}

Abbreviations: $n$, number of subjects; $\mathrm{p}$ - value.

about their supply of vitamin D (from exposure to sunlight and use of supplements) and clinical observations are needed for estimation of vitamin D status.

The present study indicated no significant difference in serum vitamin D levels of women classified as having adequate or inadequate sun exposure and no correlation between serum 25(OH)D levels and reported duration of sun exposure. Information on sun exposure was self-reported, and may have been biased due to imprecise recall ${ }^{38,39}$ and misinterpretation by the interviewer of the information

Table 3 Distribution of quantitative variables according to vitamin D cutoff classification as deficient [ $<20 \mathrm{ng} / \mathrm{mL}]$ and adequate $[\geq 20 \mathrm{ng} / \mathrm{mL}]$ ) vitamin D levels.

\begin{tabular}{|c|c|c|c|}
\hline & \multicolumn{2}{|l|}{ Vitamin D levels } & \multirow[t]{2}{*}{$p$} \\
\hline & $\begin{array}{l}<20 \mathrm{ng} / \mathrm{mL}(n=24) \\
\text { Median (IQR) }\end{array}$ & $\begin{array}{l}\geq 20 \mathrm{ng} / \mathrm{mL}(n=67) \\
\text { Median (IQR) }\end{array}$ & \\
\hline Age (years) & $54.5(47.5-57.0)$ & $54.0(49.0-60.0)$ & 0.36 \\
\hline BMI $\left(\mathrm{kg} / \mathrm{m}^{2}\right)$ & $28.9(24.9-31.9)$ & $26.4(23.8-28.8)$ & 0.15 \\
\hline Calcium ion (mmol/L) & $1.09(1.08-1.11)$ & $1.1(1.06-1.13)$ & 0.97 \\
\hline Glucose (mg/dL) & $93.5(80.0-101.0)$ & $89.3(79.0-94.0)$ & 0.55 \\
\hline Total cholesterol (mg/dL) & $200.9(176.5-218.0)$ & $182.1(158.0-203.0)$ & 0.03 \\
\hline $\mathrm{HDL}-\mathrm{C}(\mathrm{mg} / \mathrm{dL})$ & $44.3(37.0-50.5)$ & $47.5(37.0-56.0)$ & 0.30 \\
\hline Triglycerides (mg/dL) & $129.5(78.5-172.0)$ & $110.1(73.0-130.0)$ & 0.25 \\
\hline Creatinine (mg/dL) & $0.77(0.70-0.83)$ & $0.81(0.70-0.90)$ & 0.22 \\
\hline
\end{tabular}

Abbreviations: IQR, interquartile range; $n$, number of subjects; $p$ - value. 


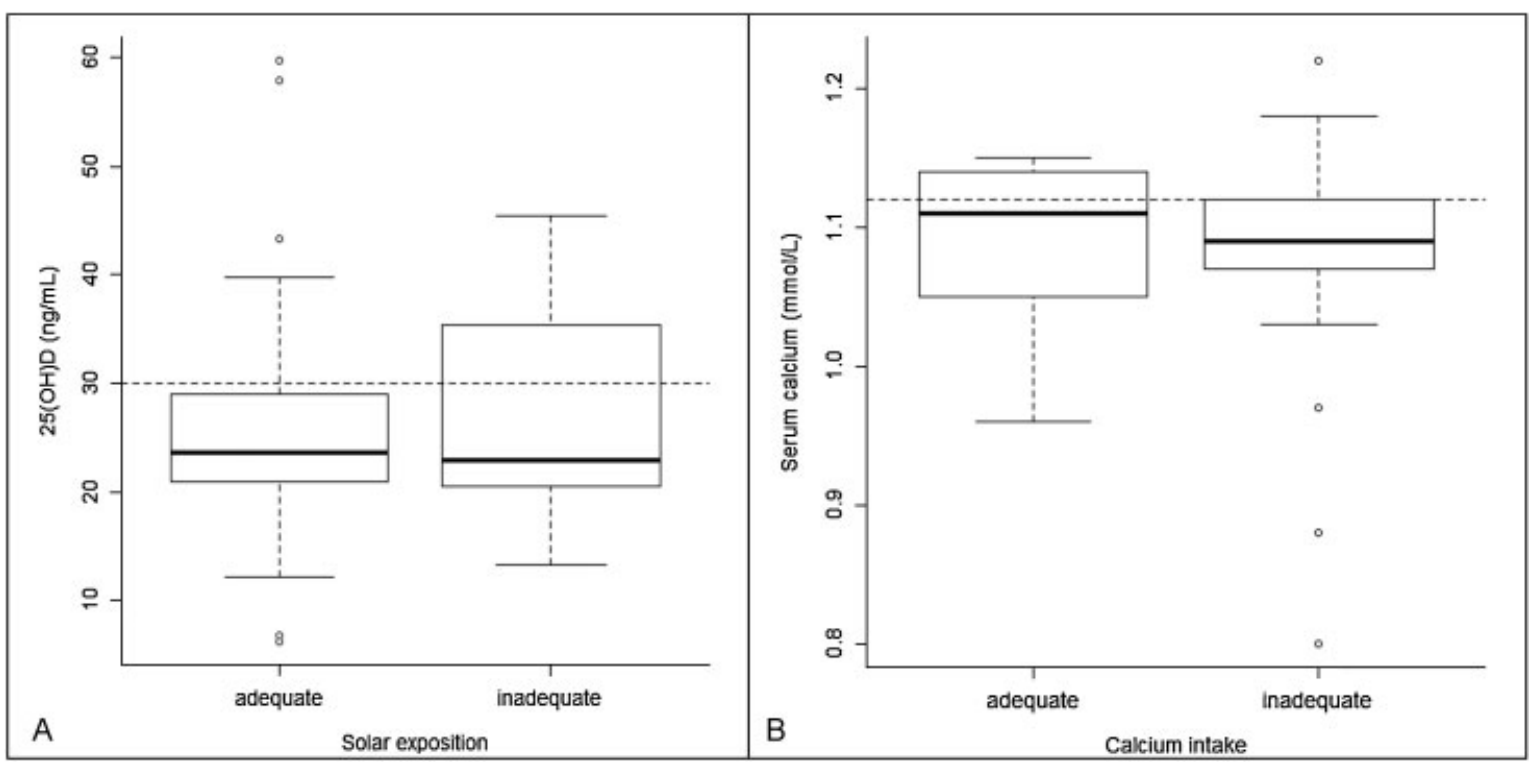

Fig. 1 Serum $25(\mathrm{OH}) \mathrm{D}$ concentrations in women with adequate and inadequate sun exposure $(A)(p=0.88)$, and serum ionized calcium concentrations $(B)(p=0.73)$ in women with adequate and inadequate calcium consumption $(n=91)$.

given by the interviewee. Consequently, the method of quantifying exposure to sunlight based on self-reporting has questionable accuracy, and more accurate methods are needed so that clinicians can provide guidelines to patients. However, it is also necessary to consider that other biological factors may interfere with $25(\mathrm{OH}) \mathrm{D}$ concentration, such as skin color. ${ }^{40,41}$ We did not thoroughly evaluate skin color in the present study by use of phototyping. ${ }^{42}$ It should be noted that dark skin interferes with vitamin $\mathrm{D}$ synthesis, and there is extensive racial mixing in the Brazilian population. ${ }^{41} \mathrm{~A}$ previous study conducted in São Paulo reported a high prevalence of hypovitaminosis $\mathrm{D}$ and secondary hyperparathyroidism in the sample population after the end of winter, and skin color significantly and independently correlated with this condition. ${ }^{43}$

Most subjects in the present study had a self-reported calcium consumption of less than $1200 \mathrm{mg} /$ day, the minimum recommended by the Institute of Medicine in the dietary reference intake of calcium. ${ }^{44} \mathrm{~A}$ previous study had reported similar results (calcium comsumption less than the minimum) for people residing in the state of São Paulo: an average of only $448 \mathrm{mg} /$ day of calcium; although reported intake did not correlate with blood level of calcium, although intake did

Table 4 Multiple linear regression analysis of the effects of sun exposure (less than three times per week versus three or more times per week), age, and serum creatinine on serum 25(OH)D concentration $(n=91)$

\begin{tabular}{|l|l|l|l|}
\hline Variable & Odds Ratio & $95 \% \mathrm{Cl}$ & $\boldsymbol{p}$ \\
\hline Intercept & 5.63 & $-14.09,25.34$ & 0.57 \\
\hline Sun exposure & 0.36 & $-4.16,4.87$ & 0.88 \\
\hline Age & -0.03 & $-0.32,0.26$ & 0.83 \\
\hline Serum creatinine & 28.11 & $10.36,45.86$ & $<0.01$ \\
\hline
\end{tabular}

Abbreviations: $\mathrm{Cl}$, confidence interval $\mathrm{p}$ - value. not correlate with reported intake or blood level of calcium. ${ }^{45}$ We also found no correlation between serum calcium and recall of calcium consumption or between serum calcium and the presence of 25(OH)D deficiency/insufficiency. It is known that calcium sensors in the parathyroid glands sense a change in circulating calcium, and this leads to increased PTH synthesis, and maintenance of blood calcium within the normal range. ${ }^{46}$ This may partially explain the absence, in the present study, of a correlation between self-reported calcium consumption and serum level of calcium ion.

Our multiple linear regression analysis demonstrated that a serum creatinine level in the normal range had a significant and independent association with higher serum 25(OH)D concentration. Previous research indicated that in the absence of renal insufficiency, the renal production of 1,25 $(\mathrm{OH})_{2} \mathrm{D}$, the hydroxylation product of $25(\mathrm{OH}) \mathrm{D}$, is normal, ${ }^{47}$ but that renal insufficiency, which is associated with abnormally high serum creatinine, is associated with a low level of serum 25(OH)D. ${ }^{48,49}$

Finally, the present findings support the need for a more objective evaluation of calcium and vitamin $D$ supply, possibly by means of a 24-hour home diary. ${ }^{50}$ Patient recall about the duration of sun exposure and calcium intake was not effective in assessing the actual levels of these substances in the present population. Although most of our study population had 25 $(\mathrm{OH}) \mathrm{D}$ insufficiency, there was no higher prevalence of arterial hypertension in women with insufficient 25(OH)D levels. However, the present study was limited due to the sample allocation being restricted to a climacteric outpatient clinic, which can potentially mean that our outcomes may not be applicable to other populations.

\section{Conclusion}

This study indicates that even in community-dwelling women living in a city under high sun exposure, levels of serum 
$25(\mathrm{OH}) \mathrm{D}>30 \mathrm{ng} / \mathrm{ml}$ are hardly reached, leading to the conclusion that other intrinsic factors besides sun exposure may regulate vitamin $\mathrm{D}$ levels.

\section{Acknowledgments}

We are grateful to Océlia de Vasconcelos for her important technical contribution to the present study.

\section{References}

1 de Paula FJ, Rosen CJ. Vitamin D safety and requirements. Arch Biochem Biophys 2012;523(01):64-72

2 Holick MF, Chen TC. Vitamin D deficiency: a worldwide problem with health consequences. Am J Clin Nutr 2008;87(04): 1080S-1086S

3 Rosen CJ, Abrams SA, Aloia JF, et al. IOM committee members respond to Endocrine Society vitamin D guideline. J Clin Endocrinol Metab 2012;97(04):1146-1152

4 Holick MF, Binkley NC, Bischoff-Ferrari HA, et al; Endocrine Society. Evaluation, treatment, and prevention of vitamin D deficiency: an Endocrine Society clinical practice guideline. J Clin Endocrinol Metab 2011;96(07):1911-1930

5 Hagenau T, Vest R, Gissel TN, et al. Global vitamin D levels in relation to age, gender, skin pigmentation and latitude: an ecologic meta-regression analysis. Osteoporos Int 2009;20(01): 133-140

6 Bischoff-Ferrari HA, Dawson-Hughes B, Staehelin HB, et al. Fall prevention with supplemental and active forms of vitamin D: a meta-analysis of randomised controlled trials. BMJ 2009;339: b3692

7 Esteghamati A, Aryan Z, Esteghamati A, Nakhjavani M. Differences in vitamin $\mathrm{D}$ concentration between metabolically healthy and unhealthy obese adults: associations with inflammatory and cardiometabolic markers in 4391 subjects. Diabetes Metab 2014;40(05):347-355

8 Oliveira RM, Novaes JF, Azeredo LM, Cândido AP, Leite IC. Association of vitamin D insufficiency with adiposity and metabolic disorders in Brazilian adolescents. Public Health Nutr 2014; 17(04):787-794

9 Buyukinan M, Ozen S, Kokkun S, Saz EU. The relation of vitamin D deficiency with puberty and insulin resistance in obese children and adolescents. J Pediatr Endocrinol Metab 2012;25(1-2):83-87

10 Kmieć P, Żmijewski M, Waszak P, Sworczak K, Lizakowska-Kmieć M. Vitamin D deficiency during winter months among an adult, predominantly urban, population in Northern Poland. Endokrynol Pol 2014;65(02):105-113

11 Dusso AS, Brown AJ, Slatopolsky E. Vitamin D. Am J Physiol Renal Physiol 2005;289(01):F8-F28

12 Health Quality Ontario.Clinical utility of vitamin d testing: an evidence-based analysis. Ont Health Technol Assess Ser 2010; 10(02):1-93

13 Peters BS, dos Santos LC, Fisberg M, Wood RJ, Martini LA. Prevalence of vitamin D insufficiency in Brazilian adolescents. Ann Nutr Metab 2009;54(01):15-21

14 Babur Guler G, Guler E, Hatipoglu S, et al. Assessment of 25-OH vitamin $\mathrm{D}$ levels and abnormal blood pressure response in female patients with cardiac syndrome X. Anatol J Cardiol 2016

15 Zhang LL, Lu YH, Cheng XL, Liu MY, Sun BR, Li CL. [A survey of correlation between serum 25-hydroxyvitamin $\mathrm{D}$ levels and dyslipidemia rlsk among middle-aged individuals in Beijing]. Zhonghua Nei Ke Za Zhi 2016;55(08):599-603

16 Grados F, Brazier M, Kamel S, et al. Prediction of bone mass density variation by bone remodeling markers in postmenopausal women with vitamin D insufficiency treated with calcium and vitamin D supplementation. J Clin Endocrinol Metab 2003; 88(11):5175-5179

17 Holick MF. Sunlight and vitamin D for bone health and prevention of autoimmune diseases, cancers, and cardiovascular disease. Am J Clin Nutr 2004;80(6, Suppl)1678S-1688S

18 Saraiva GL, Cendoroglo MS, Ramos LR, et al. Prevalence of vitamin D deficiency, insufficiency and secondary hyperparathyroidism in the elderly inpatients and living in the community of the city of São Paulo, Brazil. Arq Bras Endocrinol Metabol 2007;51(03): 437-442

19 Abdel-Gayoum AA. Serum vitamin D and parathyroid hormone profiles in patients with various stages of renal disease. Australas Med J 2015;8(02):33-40

20 United States Department of Agriculture. Agricultural Research Service [Internet]. National Nutrient Database for Standard Reference. 2014 [cited 2014 Sep 19]. Available from: http://ndb.nal. usda.gov/ndb

21 Lupash E, Ed. ACSM's guidelines for exercise testing. 9th ed. Baltimore: Wolters Kluwer; 2013

22 Bandeira F, Griz L, Freese E, et al. Vitamin D deficiency and its relationship with bone mineral density among postmenopausal women living in the tropics. Arq Bras Endocrinol Metabol 2010; 54(02):227-232

23 Pilz S, Gaksch M, Kienreich K, et al. Effects of vitamin D on blood pressure and cardiovascular risk factors: a randomized controlled trial. Hypertension 2015;65(06):1195-1201

24 Scragg R, Slow S, Stewart AW, et al. Long-term high-dose vitamin D3 supplementation and blood pressure in healthy adults: a randomized controlled trial. Hypertension 2014;64(04):725-730

25 Ponda MP, Dowd K, Finkielstein D, Holt PR, Breslow JL. The shortterm effects of vitamin $D$ repletion on cholesterol: a randomized, placebo-controlled trial. Arterioscler Thromb Vasc Biol 2012; 32(10):2510-2515

26 Lopes JB, Fernandes GH, Takayama L, Figueiredo CP, Pereira RM. A predictive model of vitamin $\mathrm{D}$ insufficiency in older community people: from the São Paulo Aging \& Health Study (SPAH). Maturitas 2014;78(04):335-340

27 Maeda SS, Saraiva GL, Hayashi LF, et al. Seasonal variation in the serum 25-hydroxyvitamin D levels of young and elderly active and inactive adults in São Paulo, Brazil: The São PAulo Vitamin D Evaluation Study (SPADES). Dermatoendocrinol 2013;5(01): 211-217

28 Lips P. Vitamin D deficiency and secondary hyperparathyroidism in the elderly: consequences for bone loss and fractures and therapeutic implications. Endocr Rev 2001;22(04):477-501

29 Lips P, Duong T, Oleksik A, et al. A global study of vitamin D status and parathyroid function in postmenopausal women with osteoporosis: baseline data from the multiple outcomes of raloxifene evaluation clinical trial. J Clin Endocrinol Metab 2001;86(03): 1212-1221

30 Cauley JA, Lacroix AZ, Wu L, et al. Serum 25-hydroxyvitamin D concentrations and risk for hip fractures. Ann Intern Med 2008; 149(04):242-250

31 Torbergsen AC, Watne LO, Wyller TB, et al. Vitamin K1 and 25(OH) $\mathrm{D}$ are independently and synergistically associated with a risk for hip fracture in an elderly population: a case control study. Clin Nutr 2015;34(01):101-106

32 Pinheiro MM, Ciconelli RM, Martini LA, Ferraz MB. Clinical risk factors for osteoporotic fractures in Brazilian women and men: the Brazilian Osteoporosis Study (BRAZOS). Osteoporos Int 2009; 20(03):399-408

33 Ramalho AC, Lazaretti-Castro M, Hauache O, et al. Fractures of the proximal femur: correlation with vitamin $\mathrm{D}$ receptor gene polymorphism. Braz J Med Biol Res 1998;31(07):921-927

34 Houston LA, Grant SF, Reid DM, Ralston SH. Vitamin D receptor polymorphism, bone mineral density, and osteoporotic vertebral fracture: studies in a UK population. Bone 1996;18(03):249252 
35 Bouillon R, Van Schoor NM, Gielen E, et al. Optimal vitamin D status: a critical analysis on the basis of evidence-based medicine. J Clin Endocrinol Metab 2013;98(08):E1283-E1304

36 Vitamin D: chasing a myth? Lancet Diabetes Endocrinol 2014; 2(01):1. Doi: 10.1016/S22138587(13)701645

37 Autier P, Boniol M, Pizot C, Mullie P. Vitamin D status and ill health: a systematic review. Lancet Diabetes Endocrinol 2014; 2(01):76-89

38 Worthen JB, Roark B. Free recall accuracy for common and bizarre verbal information. Am J Psychol 2002;115(03):377-394

39 Suinn RM, Osborne D, Winfree P. The self-concept and accuracy of recall of inconsistent self-related information. J Clin Psychol 1962;18:473-474

40 Clemens TL, Adams JS, Henderson SL, Holick MF. Increased skin pigment reduces the capacity of skin to synthesise vitamin D3. Lancet 1982;1(8263):74-76

41 Libon F, Cavalier E, Nikkels AF. Skin color is relevant to vitamin D synthesis. Dermatology 2013;227(03):250-254

42 Pérez Ferriols A, Aguilera J, Aguilera P, et al; del Grupo Español de Fotobiología. Determination of minimal erythema dose and anomalous reactions to UVA radiation by skin phototype. Actas Dermosifiliogr 2014;105(08):780-788

43 Unger MD, Cuppari L, Titan SM, et al. Vitamin D status in a sunny country: where has the sun gone? Clin Nutr 2010;29(06):784-788
44 Institute of Medicine. Standing Committee on the Scientific Evaluation of Dietary Reference Intakes. Dietary reference intakes for calcium, phosphorus, magnesium, vitamin D, and fluoride. Washington, DC: National Academies Press; 1997

45 Bueno MB, Cesar CL, Martini LA, Fisberg RM. Dietary calcium intake and overweight: an epidemiologic view. Nutrition 2008; 24(11-12):1110-1115

46 Naveh-Many T, Silver J. Regulation of parathyroid hormone gene expression by hypocalcemia, hypercalcemia, and vitamin D in the rat. J Clin Invest 1990;86(04):1313-1319

47 Caniggia A, Lorè F, di Cairano G, Nuti R. Main endocrine modulators of vitamin D hydroxylases in human pathophysiology. J Steroid Biochem 1987;27(4-6):815-824

48 Kim CS, Kim SW. Vitamin D and chronic kidney disease. Korean J Intern Med 2014;29(04):416-427

49 Lee $\mathrm{YH}$, Kim JE, Roh YH, et al. The combination of vitamin D deficiency and mild to moderate chronic kidney disease is associated with low bone mineral density and deteriorated femoral microarchitecture: results from the KNHANES 2008-2011. J Clin Endocrinol Metab 2014;99(10):3879-3888

50 Pinheiro MM, Schuch NJ, Genaro PS, Ciconelli RM, Ferraz MB, Martini LA. Nutrient intakes related to osteoporotic fractures in men and women-the Brazilian Osteoporosis Study (BRAZOS). Nutr J 2009;8:6 